\title{
Ethical Hegemony
}

Open-Access (Uncorrected) Preprint Version

\section{Do Not Cite!}

Publication version available in Rethinking Marxism, Volume 21, Issue 3 July 2009 , pages 355 - 365.

DOI: $10.1080 / 08935690902955062$

Dr. P. Kerim Friedman

Assistant Professor

National Dong Hwa University

Department of Indigenous Cultures

No. 1, Sec. 2, Da Hsueh Rd.,

Shoufeng, Hualien 97401

Taiwan

http://kerim.oxus.net/ 
FRIEDMAN, Ethical Hegemony (Preprint)

\section{Ethical Hegemony}

In Peter Ives' book, Gramsci's Politics of Language (Ives 2004), he argues that by better understanding Gramsci's theory of language we can better understand his concept of hegemony. Specifically, we can come to see "how his concept of hegemony is not only sociological but also moral and ethical" (Ives 2004: 19). That hegemony is a moral and ethical concept is important for Ives because it allows him to distinguish between progressive and repressive forms of hegemony (Ives 2004: 19). The possibility of creating a progressive hegemony is what motivates Gramsci's politics, as well as that of Peter Ives, who ends his book with a call for "critical change" (Ives 2004: 178). Although Ives does not mention sociologists like Pierre Bourdieu by name, it is precisely the difficulty of conceptualizing a progressive alternative within his theory of the habitus which has frequently led progressive intellectuals who might otherwise be drawn to his work to turn to Gramsci. After exploring the link between Gramsci's theory of language and his concept of hegemony as discussed in Ives' book, I will return to Bourdieu's theory in order to explore in more detail how Bourdieu's own theory of language differs from that of Gramsci, as well as to examine how Bourdieu's sociological theory articulates with the ethical dimensions of Gramsci's theory as spelled out by Peter Ives. Specifically, I make two claims about the differences between these two theorists: First, I argue that despite the equal emphasis both Gramsci and Bourdieu place on the historically contingent nature of society's prevailing norms, only Gramsci's historical method allows for the possibility of articulating a progressive hegemony capable of challenging these norms. Second, I argue that Bourdieu's theory of symbolic capital allows us 
FRIEDMAN, Ethical Hegemony (Preprint)

to usefully distinguish prestige from hegemony, thus overcoming a limitation of Gramsci's writings. Because Gramsci conflates these two terms, he is unable to fully theorize the obstacles facing organic intellectuals who wish to promote an alternative hegemony.

In using Bourdieu as an interlocutor, I am following the methodology of Ives' book, which consists of a series of interrogations of the linguistic writings of members of the Bakhtin Circle and the Frankfurt School, each of which serves to illustrate Ives' central point, which is that "all language takes place within normative contexts, however spontaneous they may appear" (Ives 2004: 176), a stance which he sees as central for understanding Gramsci's political theory. This is crucial for Ives, as it holds out the possibility of distinguishing progressive and repressive forms of hegemony. Ives' ethical conception of hegemony is directly derived from Gramsci's distinction between "normative" and "spontaneous" grammars. In fact, Ives goes so far as to define hegemony as "the relationship between spontaneous grammar and the prevailing normative grammar" (Ives 2004: 50). In his first chapter, Ives, drawing on Lo Piparo, provides a genealogical argument for the importance of these terms, tracing them back to Gramsci's college studies in linguistics with Matteo Bartoli. Bartoli, we learn, saw his own work as opposed to that of the Neogrammarians who believed that immutable phonetic laws drive linguistic change. Bartoli believed instead that "all languages are the historical result of sociocultural conflict" (Ives 2004: 25), with dominant languages supplanting those with less prestige. Ives cites Lo Piparo to argue that it is from this Bartolian concept of prestige that the term hegemony arises, for at this time "the terms prestigio (prestige), dittatura (dictatorship), and egemonia (hegemony) were being used 
almost synonymously" (Ives 2004: 27). But Ives' doesn't just want to show a genealogical link between Gramsci's later theories and his early work in linguistics, he shows that these issues remained central to Gramsci throughout his life, influencing all aspects of his thought.

\section{Spontaneous vs. Normative Grammar}

Before we proceed further, it is necessary to define what Gramsci meant by the distinction between spontaneous and normative grammar. Because of the numerous connotations retained by both terms, this is best done by process of elimination, excluding the most obvious misunderstandings implied by their everyday meanings. By the phrase "spontaneous" Gramsci did not mean to imply what linguists call "universal grammar," the underlying genetic structures in our brain which allow us to learn a language. Nor did he mean to refer to dialects or other non-standard language varieties as opposed to the standard language, although that is somewhat closer to Gramsci's meaning. The difference being that spontaneous grammars are influenced by the history of a people as well as the history of an individual. As such, "The number of 'immanent or spontaneous grammars' is incalculable and, theoretically, one can say that each person has a grammar of her own" (Ives 2004: 42). In fact, the term spontaneous seems uniquely unsuited for the uses Gramsci put the word to:

His 'spontaneous grammar' is not spontaneous at all; rather, it is created throughout the molecular processes of learning a language from birth throughout one's entire life. This process of sedimentation is affected by religion, class, gender, and geographic location (i.e., dialect). In different 
FRIEDMAN, Ethical Hegemony (Preprint)

circumstances, many of these processes contain different normative grammars.

(Ives 2004: 44)

From this quote we also learn that spontaneous grammar is not simply the opposite of normative grammar. What distinguishes the two seems to be the process by which they are formed. The former is produced from the life-history of an individual. As such, spontaneous grammar is shaped by the linguistic norms explicitly laid down according to past and present normative grammars, but is not reducible to those norms. Normative grammar, on the other hand, is the attempt to impose these norms on the population either informally, or by encoding them in grammar books, or even in the law. As such, normative grammar "amounts to the exercise of power and law (even if informal customary law, as in the case of the peasant who moves to the city) over some people" (Ives 2004: 42).

This definition makes clear that the phrase normative grammar does not simply refer to the standard variety of a language, but refers more specifically to the process of standardization a process which can result in multiple standards through the lifetime of a language. And it is here that the ethical element enters into the equation, for this process of standardization can either be democratic, resulting in a normative grammar closely tied to the preexisting spontaneous grammars of the people, serving as a unifying force, or it can be divorced from those spontaneous grammars and function as a repressive force by deligitimating everyday speech. In the Marxist-inspired linguistics of Bakhtin, to whom we now turn, it is inconceivable that a grammar could be both normative and democratic at the same time. 


\section{Linguistic Utopias vs. Vernacular Materialism}

The practical implications of Gramsci's theory of language come into focus through Ives interrogation of various visions of linguistic utopias: Croce's "pure expression," Esperanto, Bakhtin's heteroglossia, "polyglot Europe," Benjamin's "the language of things," "mimesis" in Horkheimer and Adorno, and Habermas' "undistorted communication." Each of these utopias is carefully compared and contrasted with Gramsci's own "vernacular materialism," a phrase coined by Ives to highlight the impossibility of opposing language to "the 'matter' of the 'real' world" (Ives 2004: 5). The definition of this term is slowly shaped through a series of critical encounters with each of these various linguistic utopias. The end result is not simply an exegesis of Gramsci's ideas, but a perceptible shift in the geography of each of these linguistic utopias. In my mind, the most significant contribution is our richer understanding, as a result of these critical encounters, of Gramsci's own utopian-sounding devices: the organic intellectual, spontaneous philosophy, and progressive hegemony. Ives argues forcefully that these devices merely sound utopian, and I think he is correct that, anchored as they are in the Italian context in which Gramsci was politically active, these concepts are resolutely anti-utopian.

This anti-utopianism is seen most clearly in Gramsci's support of a unified Italian language. Ives quotes his letter rejecting a request by the Milan section of socialist party to support Esperanto as the official language of Italy. In it Gramsci argues that while a truly 
international communist society may create the linguistic conditions within which linguistic unification could take place, such change must happen organically, "from the bottom upwards" and cannot be imposed from above (Ives 2004: 32). Moreover, the choice of language must derive from democratic, bottom-up processes:

Instead of trying to impose a normative grammar on a people, be it the normative grammar of Esperanto or some specific dialect like Tuscan, it would be more ethical and more pragmatic to develop a native grammar that did not have to manage these various frictions but instead was itself the product of their resolution. (Ives 2004: 51)

Just as Gramsci argued that Italian communism had to follow its own unique path before Italians were ready to join in an international movement, so too did he believe that linguistic unification in Italy had to arise organically out of the Italian language, thus rejecting the possibility of imposing an alien language like Esperanto.

Ives later returns to this argument in light of his discussion of Bakhtin, whose advocacy of heteroglossia, a term which refers to multi-vocality or linguistic heterogeneity, seems to contrast sharply with Gramsci's call for Italian linguistic unification:

Gramsci's advocacy of a unified national langauge - which I have argued is a metaphor for hegemony - is met by Bakhtin with an almost equally strong disdain. (Ives 2004: 72) 
Ives explains this difference of opinion in terms of their different careers (the scholar vs. the politician), but also (and more importantly) in terms of the different contexts in which they worked:

As noted earlier, Bakhtin is absorbed with Stalin's centralization of everything involving culture and language. Gramsci is preoccupied with the disorganization and chaos of a working-class movement [i.e. the biennio rosso uprising of 1919] that ended in defeat. (Ives 2004: 72)

Despite these differences, however, Ives sees their fundamental conception of language as being remarkably similar. While some scholars portray heteroglossia as an essentially normative view of langauge, Ives argues that "heteroglossia is not an inherent aspect of language itself, but rather an aspect of the social world in which language resides" (Ives 2004: 78). This is important because it rescues Bakhtin's approach from the uncomfortable stance of having to declare that monological language is somehow antithetical to the very nature of language:

Defining heteroglossia as the manifestation of social diversity in language has two important implications. First, without divorcing language from everyday life, it makes the issue of whether language is heteroglottic irrelevant by focusing on the strong connections between languages and social activity ... Second, it avoids reductions that heteroglossia is necessarily good and democratic whereas monoglossia is inherently bad and antidemocratic. (Ives 
Whether or not we consider heteroglossia to be desirable, there is no reason to therefore define language as inherently heteroglossic, and indeed Ives finds that while Bakhtin was inconsistent on the matter, he tended to take the position that "heteroglossia is not an inherent aspect of language itself, but rather an aspect of the social world in which language resides" (Ives 2004: 78). This holds open the possibility - essential for Ives' argument - of a progressive hegemony in which a top-down monologic standard is replaced with one that is democratically generated from the bottom up. This is precisely Gramsci's vision of linguistic unification in Italy, which he felt was necessary to overcome the fragmentation of the subaltern classes (Ives 2004: 77, 82-83)

As Ives states, Gramsci's position is a "political and moral argument, not a factual one" (Ives 2004: 94). There is no such thing as a truly monological linguistic community (Lippi-Green 1997). Nor did Gramsci seem to consider linguistic heterogeneity to be a bad thing. In a letter he wrote from prison to his sister, he insisted that his nephew be allowed to continue to speak Sardinian, his mother-tongue, at home (Ives 2004: 43). Gramsci did not see linguistic unification as requiring the suppression of local language varieties, although he seemingly didn't mind if this were a long-term consequence of such a policy.

What Gramsci cared about was creating the social conditions necessary for a democratic linguistic unification. His emphasis was on the process rather than the product of such a unification, thus eliding the differences in emphasis between him and Bakhtin with regard to 
their final goals. However, this emphasis on process also highlights an important difference between the two thinkers: their thinking about the role played by intellectuals in bringing about linguistic change.

linguists and philosophers of language have functioned as traditional intellectuals, by obscuring challenges to the status quo. Bakhtin does not allow any role for organic intellectuals, who could highlight this mutability of language and still work toward creating a unified language by different means. (Ives 2004: 82)

Organic intellectuals are crucial to a theory of hegemony defined (in Ives terms) as "the relationship between spontaneous grammar and the prevailing normative grammar," and which sees "the goal of ... any progressive social force" as working out the tension between the two "by paying careful attention to the formation of the normative grammar in the first place" (Ives 2004: 50). This definition of hegemony, emphasizing as it does the role played by cultural and linguistic norms in maintaining social inequality, has a strong resemblance to Bourdieu's theory of the habitus. And yet, as we have seen with Bakhtin, Gramsci's emphasis on the role of intellectuals in bringing about social change holds out the possibility of a progressive hegemony which remains under-theorized in Bourdieu's work. It is to these similarities and differences that we now turn.

\section{Is habitus just another word for hegemony?}


At first brush, Gramsci's theoretical framework seems to map easily onto that of Bourdieu. Take, for instance, Gramsci's conception of spontaneous grammar, "created throughout the molecular processes of learning a language from birth throughout one's entire life" (Ives 2004: 44). This bears a striking similarity to John Thompson's description of Bourdieu's theory of the habitus:

The habitus is a set of dispositions which incline agents to act and react in certain ways. The dispositions generate practices, perceptions and attitudes which are 'regular' without being consciously co-ordinated or governed by any 'rule." ... Dispositions are acquired through a gradual process of inculcation in which early childhood experiences are particularly important. (Thompson 1991: 12).

Both spontaneous grammar and the habitus are the product of each individual's own life history, with class differences emerging out of the different opportunities and experiences available to those individuals.

What confuses the issue, however, is that the concept of habitus shares equally strong similarities with Gramsci's concept of normative grammar.

'[Normative grammar] is constituted by reciprocal control, by reciprocal teaching, and by reciprocal "censorship," which manifest themselves with the questions: "What did you intend, or want to say?", "Explain yourself better," etc... With caricature and teasing, this whole complex of actions and reactions 
combines to determine a grammatical conformism, to establish "norms" or judgements of correctness and incorrectness, etc.' (Gramsci cited in Ives 2004: 41)

Again, compare this with Thompson's account of the habitus:

Through a myriad of mundane processes of training and learning, such as those involved in the inculcation of table manners ('sit up straight', 'don't eat with your mouth full', etc.), the individual acquires a set of dispositions which literally mould the body and become second nature. The dispositions produced thereby are also structured in the sense that they unavoidably reflect the social conditions within which they were acquired (Thompson 1991: 12).

Habitus seems to contain elements of both spontaneous and normative grammar. But since Gramsci himself viewed spontaneous grammar as the product of interaction with numerous normative grammars, and hegemony is, as Ives shows us, the relationship between spontaneous and normative grammar, it is easy to see why some scholars might find the terms habitus and hegemony to be interchangeable.

To equate the two terms, however, would be to ignore the lesson we have learned from Ives' book. Namely, that despite their similarities, spontaneous and normative grammars are the results of very different social processes. The former arises out of the life-histories of individuals, and the latter is the result of conscious political processes. Gramsci's work attempts to theorize these social processes, whereas (as discussed below) Bourdieu's work 
seemingly takes them for granted. Just as Gramsci's teacher, Bartoli, rejected the linguistic arbitraries of the Neogrammarians, so too does Gramsci argue that choice of normative grammar is anything but arbitrary. We see this in Gramsci's rejection of Esperanto for its lack of connection to pre-existing spontaneous grammars. Gramsci is always careful to emphasize the role of politics in the emergence of a particular standard.

In his notebooks Gramsci takes up an essay by Croce entitled "This round table is square," a nonsense phrase chosen, like Chomsky's famous "Colorless green ideas sleep furiously," in order to illustrate the underlying logic of grammar even in situations of semantic absurdity (Gramsci 1985: 179). Gramsci counters that such an expression could have expressive meaning rather than a purely logical one. ${ }^{1}$ He then goes on to argue that

\begin{abstract}
Grammar is 'history' or 'a historical document': it is the 'photograph' of a given phase of a national (collective) language that has been formed historically and is continuously developing (Gramsci 1985: 179-80)
\end{abstract}

This highlights what I think is key difference in Gramsci's writing and that of Bourdieu. Whereas both scholars explore the institutional processes of reproducing consent, only Gramsci provides us with an account of the specific political processes by which consent is (or is not) manufactured. This explains why, as we will see in the next section, Bourdieu emphasizes formal institutions such as schools, whereas Gramsci emphasizes the role of

1. In discussing this passage Ives focuses on the fact that Croce's essay already anticipates such critique, hypothesizing that Gramsci did not have access to the original document in prison (Ives 2004: 38). While it may be true that Gramsci created a straw-man, here I would like to focus attention on what Gramsci did with his straw-man rather than the veracity of his claims. 
political parties as a socializing force.

\section{The cultural arbitrary vs. the historical bloc}

In Bourdieu's early work with Passeron, we find the term "the cultural arbitrary" used in a way which seems to quite similar to Gramsci's concept of normative grammar.

In any given social formation the cultural arbitrary which the power relations between the groups or classes making up that social formation put into the dominant position within the system of cultural arbitraries is the one which most fully, though always indirectly, expresses the objective interests (material and symbolic) of the dominant groups or classes. (Bourdieu and Passeron 1990: 9).

In developing this concept, Bourdieu draws upon William Labov's early work which showed that "members of a speech community can share allegiance to the same standard, despite differences in the (nonstandard) varieties they themselves speak" (Hanks 2005: 76). Bourdieu's work with Passeron serves to highlight how the educational system institutionalizes these arbitrary standards, thus naturalizing the success of the elite who are socialized into these norms before they even set a foot in school. In Bourdieu's terminology, people misrecognize educational success as merit, not privilege. Unlike normative grammar, however, the phrase "cultural arbitraries" reveals a lingering Saussurian structuralism. The specific content of the dominant cultural or linguistic form is less important for Bourdieu's theory than the mere existence of an arbitrary standard which is recognized as legitimate even 
by those who unable to perform it.

While Bourdieu does repeatedly emphasize the historically contingent nature of the dominant cultural and linguistic forms, it is only the fact of their institutionalization which ultimately matters for his theory of the habitus, not the process by which this institutionalization took place. The consequences of Bourdieu's emphasis on the forces of social reproduction over those of social change have been widely remarked upon, often by way of contrast with Gramsci (Friedman 2005; Haeri 1997; Jenkins 2002; Woolard 1985). For Gramsci, the content of the hegemonic cultural and linguistic forms reflects the process of their institutionalization, just as they did for his teacher Bartoli. Gramsci's theory of hegemony emphasizes the process of building political alliances between classes and thus avoids the all too easy assumption of a one-to-one fit between the material and symbolic interests of these dominant classes and the form of the cultural arbitrary which they actively promote.

In Gramsci's work, especially in his writings on "passive revolution" (Gramsci et al. 1972: 108), he employs the comparative-historical method to explain the differential development of class relations in various modern nation-states. In comparing the French and Italian bourgeois revolutions, Gramsci argues that the major difference between the two lies precisely in the ability of the Jacobins to "widen [their] class interests and to discover those interests which [they] had in common with the popular sectors" (Mouffe 2002: 295). Gramsci uses the term "passive revolution" to refer to the failure of the Italian urban bourgeoisie to do the same (Gramsci et al. 1972: 108). It is a "passive" revolution because, unlike the French case, the Italian bourgeoisie allied with the Southern aristocracy against the peasants instead 
of forging a new hegemony which would institutionalize their shared interests against those of the old order. This is also the cause of the division between the industrial workers in the North and the peasants in the South which Gramsci saw as responsible for the failure of the northern workers during the biennio rosso uprising which lasted from 1919 to 1920 (Gramsci 1957).

Gramsci's historical method serves to highlight the cross-class alliances which stabilize in any given "historical bloc" - a phrase which refers to the "complex, contradictory and discordant ensemble of the superstructures" and corresponding "relations of production" (Gramsci et al. 1972: 366). The hegemonic ideology of any given bloc does not simply reflect the interests of the ruling elite, but also those of the other classes with whom they have entered into alliances with -- and even the very process by which that alliance took shape. For instance, even though America's financial elite share a generally secular libertarian ideology, the Conservative movement was able to succeed by combining elite interests with those of evangelical southern white Christians. This has its roots in post-Civil War reconstruction and the "southern strategy" adopted by Nixon's Republican Party in the wake of the civil rights movement (Krugman 2007; Phillips 1969). Choices regarding hegemonic cultural forms are not arbitrary, nor do they simply reflect the cultural forms of the elite. They are the product of the "complex, contradictory and discordant ensemble" of a given historical bloc. While Bourdieu may tacitly acknowledge the importance of such processes, his theory of the "cultural arbitrary" retains its structuralist roots.

Another consequence of Bourdieu's focus on the mere fact of institutionalized norms as 
opposed to the process of their institutionalization is that he emphasizes the role of those intellectuals who benefit from institutional norms, and downplays the role of those who seek to change those norms. In Gramscian terms, Bourdieu focus on "traditional intellectuals" at the expense of "organic intellectuals."

A traditional intellectual simply refines and adjusts the already created organization of the world view of the dominant class. In contrast, an organic intellectual must organize more thoroughly that which is in chaos. (Ives 2004:

It is the organic intellectual's ability to translate between spontaneous and normative grammar which makes a progressive hegemony possible. Yet, despite Bourdieu's relative lack of attention to the role played by organic intellectuals, his theory of "symbolic capital" nonetheless provides us with a useful addendum to Gramsci by elaborating the hidden mechanisms through which the legitimacy of hegemonic forms are inculcated in the habitus.

\section{Prestige vs. Hegemony}

In his writing on language Bourdieu sought to challenge the reductionism of Chomskyian linguistics by highlighting the role power relations play in our evaluation of linguistic utterances:

It follows from the expanded definition of competence that a language is worth what those who speak it are worth, i.e. the power and authority in the 
FRIEDMAN, Ethical Hegemony (Preprint)

economic and cultural power relations of holders of the corresponding competence (Bourdieu 1977: 652)

We have already discussed the limitations of Bourdieu's assumption that there exists a oneto-one correspondence between the habitus of the ruling elite and the hegemonic cultural forms in a given era, but despite this limitation Bourdieu's work still offers us insight into the process by which a "social hierarchy ... is transposed into stylistic hierarchy" (Hanks 2005: 75).

For Bourdieu, symbolic systems are "structuring as well as structured," and his theory of "symbolic capital" suggests that by "engaging in linguistic practice" we become "complicit with the pervasive power relations in which [our] language is embedded" (Hanks 2005: 77). Bourdieu's use here of the market metaphor is analogous to Marx's discussion of "commodity fetishism" in which he shows that the experience of exchange relations serve to obscure the inequitable social relations of production which make commodity markets possible (Marx 1977: 163-77). Similarly, our routine engagement in linguistic exchanges is predicated upon an invisible "systems of distinction and division" which makes possible the social production of meaning (Hanks 2005: 77).

Ives informs us that in Gramsci's milieu, "the terms prestigio (prestige), dittatura (dictatorship), and egemonia (hegemony) were being used almost synonymously" (Lo Piparo, in Ives 2004: 27). I would like to conclude by suggesting that we might usefully distinguish prestige from hegemony, and that by doing so we can successfully combine Bourdieu's insight into the "structuring" nature of linguistic power structures with Gramsci's insights into 
the historical processes by which given structures become hegemonic. Doing so allows us to understand what is at stake in replacing one normative grammar with another one. From Ives' book we learn that hegemony is an inherently normative concept, and that a progressive hegemony requires a new normative grammar to be selected through democratic processes. By adding to this Bourdieu's theory of symbolic capital, we can better understand how the prestige of an existing normative grammar serves to undermine efforts to bring about a progressive hegemony. This is especially pertinent in understanding the situation faced by speakers of minority languages, for whom pluralist language policies usually mean being regulated to the bottom of a de-facto linguistic hierarchy (Friedman 2005; May 2001). Only by combining Bourdieu's insights with those of Gramsci's can we ensure that a genuinely progressive hegemony is formed through democratic processes which take into account the gap in linguistic prestige between mainstream and minority populations.

\section{Aknowledgements}

Thanks to Peter Ives and Jacinda Swanson for their generous feedback.

P. Kerim Friedman: Assistant professor in the Department of Indigenous Cultures at National Dong Hwa University in Taiwan, where he teaches linguistic and visual anthropology. He is founding member of the anthropology blog Savage Minds (savageminds.org) and a documentary filmmaker. His last film is Acting Like a Thief (D.E.R. 2005). 


\section{References}

Bourdieu, Pierre. 1977. The Economics of Linguistic Exchanges. Social Science Information 16 (6): 645-68.

Bourdieu, Pierre, and Jean-Claude Passeron. 1990. Reproduction in Education, Society, and Culture. London: Sage Press.

Friedman, P. Kerim. 2005. Learning "Local" Languages: Passive Revolution, Language Markets, and Aborigine Education in Taiwan. Temple University.

Gramsci, Antonio. 1957. The Southern Question. In The Modern Prince and Other Writings, New York, NY: International Publishers.

Gramsci, Antonio. 1985. Selections From Cultural Writings. Cambridge, MA: Harvard University Press.

Gramsci, Antonio, Quintin Hoare, and Geoffrey Nowell-Smith. 1972. Selections From the Prison Notebooks of Antonio Gramsci. New York: International Publishers.

Haeri, Niloofar. 1997. The Reproduction of Symbolic Capital: Language, State, and Class in Egypt. Current Anthropology 38 795-816.

Hanks, William, F. 2005. Pierre Bourdieu and the Practices of Language. Annual Review of Anthropology 34 (1): 67-83.

Ives, Peter. 2004. Gramsci's Politics of Language: Engaging the Bakhtin Circle and the Frankfurt School. Toronto: Univ of Toronto Press.

Jenkins, Richard. 2002. Pierre Bourdieu. Routledge.

Krugman, Paul. 2007. The Conscience of a Liberal. W. W. Norton.

Lippi-Green, Rosina. 1997. The Linguistic Facts of Life. In English With an Accent: Language, Ideology, and Discrimination in the United States, Routledge.

Marx, Karl. 1977. Capital: A Critique of Political Economy. New York: Vintage Books.

May, Stephen. 2001. Language and Minority Rights. Pearson ESL. 
Mouffe, Chantal. 2002. Hegemony and Ideology in Gramsci. In Antonio Gramsci: Critical Assessments of Leading Political Philosophers (Vol. 2), edited by James Martin, New York: Routledge.

Phillips, Kevin P. 1969. The Emerging Republican Majority. Arlington House.

Thompson, John B. 1991. Introduction. In Language and Symbolic Power, Cambridge, Mass.: Harvard University Press.

Woolard, Kathryn A. 1985. Language Variation and Cultural Hegemony: Toward an Integration of Sociolinguistic and Social Theory. American Ethnologist 12 (4): 738-48. 